\title{
Opportunities to Access to General Education of Children Living in Poverty Families in Ethnic Minority in Vietnam Nowadays
}

\author{
Nguyen Dinh Tuan ${ }^{1}$ \\ ${ }^{1}$ Institute of Human Studies, Vietnam Academy of Social Science, Vietnam \\ Correspondence: Nguyen Dinh Tuan. Email: tuanihs@yahoo.com
}

Received: April 18, 2020

doi:10.5539/ass.v16n6p43
Accepted: April 27, $2020 \quad$ Online Published: May 31, 2020

URL: https://doi.org/10.5539/ass.v16n6p43

\begin{abstract}
Education is a basic right of people and everyone has the right to access to education. The right is stated in Clause 1, Article 26 of 1948 Universal Declaration of Human Rights (UDHR). In Vietnam, the Constitution passed by the National Assembly of the Socialist Republic of Vietnam in 2013 also stipulates that education is a right of people and the State, families and the society must protect, take care of and educate children. To ensure children's right to access to education as well as to enable them to access to learning opportunities, Vietnam has promulgated many policies to create favorable conditions for all children in education, especially those from poor families and ethnic minority families in the past years. However, compared to children from well-off families, children from poor families in ethnic minority regions still face difficulties in education. Based on statistics, this article focuses on analyzing the opportunities to access to general education of children from poor families in ethnic minority regions in Vietnam nowadays.
\end{abstract}

Keywords: education, access to education, children, poverty, ethnic minority regions

\section{Introduction}

Education always plays a very important role in promoting the socio-economic development of all countries and communities, especially in the context of the vigorous development of science and technology at present. In Vietnam, education is always considered as one of its top priorities and stated in many Congresses with the viewpoint that "education is the leading national policy" (The Communist Party of Vietnam, 2016) and that investment in education means investment in people. Recognizing education's important role towards its socio-economic development and human development, Vietnam has promulgated many education policies to create opportunities for all its people to access to education, including children from poor households over the past years. However, access to education, especially higher education, is a big challenge for children living in poor ethnic minority families because the children live in mountainous, remote and/or extremely difficulty areas where house many communes belonging to the Program 135.

In Vietnam, there are 53 ethnic minorities with total of $14,122,809$ people, accounting for $14.7 \%$ of its population and they mainly live in 51/63 provinces and cities (Central Steering Committee for the Population and Housing Census, 2019). Ethnic minority areas are understood that these are the areas housing a large number of ethnic minorities stably living together as communities in the territory of the Socialist Republic of Vietnam (the Government, 2011). The ethnic minority areas have 5,266 communes (Note 1), including 1,957 in the region III and 20,139 hamlets, villages outside the region III in extremely difficult areas (the Government, 2019). The region has 64 poorest districts with a relatively high poverty rate (over 50\%) in Vietnam. By 2018, there are some areas and localities which have poverty rates much higher than the average poverty rate of the whole country such as the northwest mountainous area $(24.23 \%)$, the northeast mountainous area (12.08\%), the Central Highlands (10.36\%), Dien Bien province (37.08\%), Ha Giang province (31.17\%), and Cao Bang province (30.81\%) while the poor household percentage of Vietnam is only $5.23 \%$ (Ministry of Labor - Invalids and Social Affairs, 2019).

Children living in poor families often face disadvantages in education (Watkins, 2012) and they are difficult to fulfill their education and to find a job and they earn less money than children living in non-poor households when growing up (Coley \& Baker, 2013). From the perspective of human development, limitations in access to education affect not only on one's education improvement and awareness but also on his opportunities to access to high-income jobs and on his physical fitness due to lack of knowledge about nutrition and healthcare. Those 
with more years of schooling tend to have better health and better health awareness. Education helps maintain a healthy lifestyle and positive choices, accordingly promoting human development (Feinstein, Sabates, Anderson, Sorhaindo, \& Hammond, 2006).

Based on the data results of the Vietnam Household Living Standards Survey 2016 and the source of the General Statistics Office of Vietnam, the paper analyzes opportunities to access to general education of children living in poor families in ethnic minority areas in Vietnam at present through four dimensions: availability, accessibility, acceptability and adaptability. Children in poor households we analyze in the paper are those living in the communes under the Program 135 (Note 2).

\section{Approach and Methodology}

To evaluate the access to education, two factors often to be based on are availability and accessibility. For example, when analyzing equitable access to education, Tristan McCowan uses three factors, including two factors which are availability (it is ensured that there are sufficient schools and classes) and accessibility (support conditions for all people possible to access) (McCowan, 2015). From the perspective of education rights, it is to use 4A namely Availability, Accessibility, Acceptability, and Adaptability when mentioning about education (United Nations Human rights, 1999; Tomaševski, 2001). The General Comment No. 13 about the right to education clearly states:

- Availability: Functioning educational institutions and programs have to be available in sufficient quantity within the jurisdiction of the state party. All institutions and programs are likely to require buildings or protection from the elements, sanitation facilities for both sexes, safe drinking water, trained teachers receiving domestically competitive salaries, teaching materials, and so on.

- Accessibility: Through educational institutions and programs have to be accessible to everyone without discrimination. Accessibility has three overlapping dimensions: i) Education must be accessible to all, especially the most vulnerable groups, in law and fact, without discrimination on any of prohibited grounds; ii) Educational institutions have to be within safe physical reach at some reasonably convenient geographic locations or via modern technology (e.g. access to a "distance learning" program); iii) Education has to be affordable to all. This dimension of accessibility is subject to different educational levels. For example, primary education shall be available "free to all", state parties are required to progressively introduce free secondary and higher education.

- Acceptability: The form and substance of education, including curricula and teaching methods, have to be acceptable (e.g. relevant, culturally appropriate and of good quality) to students, in appropriate cases, parents.

- Adaptability: Education has to be flexible so it can adapt to the needs of changing societies and communities and respond to the needs of students within their diverse social and cultural settings (School of Law, Vietnam National University, Hanoi, 2009, pp. 219-220).

Though we do not evaluate the implementation of the right to education of children in this paper, we take advantage of this frame to clarify the reality of access to education of children living in poor households in ethnic minority areas in Vietnam. This frame is used by K. Tomaševski and other scholars to study education. For example, availability, accessibility, acceptability and adaptability in this paper are shown in the following dimensions: Availability: shown in educational institutions and teachers; Accessibility: shown in policies and distance from home to educational institutions; Acceptability: shown in tuition fees; Adaptability: shown in the subjectivity of students and their families.

The article is mainly based on results of the Vietnam Household Living Standards Survey 2016. This is a survey to serve policy making and socio-economic development planning, from 1993 to now the General Statistics Office conducts the Viet Nam Household Living Standards Survey (VHLSS). Since 2002, this survey has been conducted regularly by the General Statistics Office every two years. The VHLSS 2016 was conducted nationwide with a sample size of 46,995 households in 3,133 communes/wards which were representative at national, regional, urban, rural and provincial levels. The survey collected information during four periods, each period in one quarter from the first quarter to the forth quarter in 2016 through face-to-face interviews conducted by interviewers with household heads and key commune officials in communes containing sample enumeration areas (General Statistics Office of Vietnam, 2018, p. 11).

\section{Access to Education of the children living in poor families in Ethnic Minority Areas Through Four-Dimension Analysis}

\subsection{Availability}

In the past years, Vietnam has promulgated many policies focusing on infrastructure construction for poor areas 
and localities in the whole country, thereby educational institutions in such areas and localities are day by day more available and better, including school and classroom systems. The percentage of communes with schools and classrooms tends to increase. For example, for 2006-2016 period, the percentage of communes under the Program 135 (Note 3 ) with primary education increases by $0.3 \%$ (from $91.9 \%$ to $94.9 \%$ ), lower secondary by $3.8 \%$ (from $84 \%$ to $87.8 \%$ ) and upper secondary by $3.7 \%$ (from $7 \%$ to $10.7 \%$ ). As of $2018,100 \%$ communes in ethnic minority and mountainous areas have primary and secondary schools and most communes have nursery schools or classrooms. There are 314 ethnic minority boarding schools; 975 ethnic minority day schools; and five university preparatory schools for nationalities (the Government, 2018). The construction of more schools and classrooms, especially lower and upper secondary schools, creates more favorable conditions for students in poor areas and those from poor households to gain access to general education. However, when comparing such communes with those not under Program 135, the percentage is still lower, especially at lower secondary level. By 2016, the percentage of communes under the Program 135 with primary schools is $94.9 \%$, lower secondary $87.8 \%$ and upper secondary $10.7 \%$, whereas the percentage of those not under Program 135 is $99.1 \%, 92.5 \%$ and $18.9 \%$ respectively.

Table 1. Percentage of communes with different educational institutions (Unit: \%)

\begin{tabular}{|c|c|c|c|c|c|c|c|}
\hline \multirow[b]{2}{*}{ Year } & \multirow[b]{2}{*}{$\begin{array}{l}\text { Primary } \\
\text { schools }\end{array}$} & \multirow[b]{2}{*}{$\begin{array}{l}\text { Lower } \\
\text { secondary } \\
\text { schools }\end{array}$} & \multirow[b]{2}{*}{$\begin{array}{c}\text { Upper } \\
\text { secondary } \\
\text { schools }\end{array}$} & \multicolumn{3}{|c|}{ In which } & \multirow[b]{2}{*}{$\begin{array}{c}\text { Regular } \\
\text { education } \\
\text { center }\end{array}$} \\
\hline & & & & $\begin{array}{c}\text { Combined } \\
\text { primary school } \\
\text { and lower } \\
\text { secondary school }\end{array}$ & $\begin{array}{l}\text { Combined } \\
\text { lower and upper } \\
\text { secondary } \\
\text { school }\end{array}$ & $\begin{array}{l}\text { Primary school } \\
\text { and lower, upper } \\
\text { secondary school }\end{array}$ & \\
\hline \multicolumn{8}{|c|}{ Communes under the Program 135} \\
\hline 2006 & 91.9 & 84.0 & 7.0 & 18.1 & 3.6 & - & 1.6 \\
\hline 2008 & 96.8 & 87.5 & 8.0 & 13.5 & 2.8 & - & 1.3 \\
\hline 2010 & 93.7 & 86.1 & 10.0 & 15.2 & 5.0 & 0.9 & 2.6 \\
\hline 2012 & 94.3 & 87.1 & 10,8 & 13.2 & 2.6 & - & 2.4 \\
\hline 2014 & 94.9 & 88.7 & 13.0 & 9.6 & 3.4 & - & 2.6 \\
\hline 2016 & 94.9 & 87.8 & 10.7 & 11.6 & 3.3 & 0.7 & 2.0 \\
\hline \multicolumn{8}{|c|}{ Communes not under the Program 135} \\
\hline 2006 & 98,9 & 91,9 & 15.3 & 5.5 & 3.4 & 0.3 & 3.8 \\
\hline 2008 & 99.2 & 92.5 & 16.3 & 3.7 & 2.3 & 0.2 & 3.4 \\
\hline 2010 & 99.5 & 92.0 & 18.0 & 4.7 & 2.9 & 0.5 & 4.3 \\
\hline 2012 & 99.2 & 92.3 & 18.6 & 3.8 & 2.3 & 0.6 & 3.4 \\
\hline 2014 & 99.2 & 92.1 & 18.4 & 4.7 & 3.2 & 0.4 & 3.7 \\
\hline 2016 & 99.1 & 92.5 & 18.9 & 3.6 & 2.5 & 0.6 & 3.0 \\
\hline
\end{tabular}

Source: General Statistics Office of Vietnam, 2018, p. 731.

In terms of teachers, in such poor provinces as Dien Bien, Ha Giang, Lai Chau, Bac Kan, Lang Son, etc. the percentage of students/teachers is lower than the national average level. For example, in 2018, students/teachers rate at the national lower secondary level is 20.6 but in Dien Bien is 15.6, Ha Giang 14.8, Lai Chau 15.8, Bac Kan 14.5 and Lang Son 13.9 (Note 4). As the number of students/teachers in more poor localities is lower than the national average level and thus, children in poor areas require conditions to gain access to education. However, it does not mean that teachers are available in all poor localities in ethnic minority areas because some extremely disadvantaged localities are still lack of teachers (Hoa, 2013).

\subsection{Accessibility}

\subsubsection{In Terms of Policies}

The Constitution 2013 of Vietnam has defined education is a human right and the State, families and society have to protect, take care of and educate children (the National Assembly of the Socialist Republic of Vietnam 2013). Education development is considered the leading national policy to improve people's knowledge, develop human resources, foster talents; and ensure that primary education is compulsory and free; universalize step by step lower secondary education; the State gives a priority to develop education in mountainous, island and ethnic 
minority areas and especially difficult socio-economic areas; to recruit and promote talents; and to enable the disabled and the poor to attend cultural and vocational training courses (the National Assembly of the Socialist Republic of Vietnam, 2013). The provisions of the Constitution are clarified in the Law on Education 2019 of the National Assembly of the Socialist Republic of Vietnam. The law clearly stipulates the equality in learning opportunities for all citizens and the State has issued many policies to give priorities and enable children with disadvantaged conditions, the disabled and those from poor and to-be-poor households to gain access to education.

The 2011-2020 education development strategy of Vietnam also clearly states its viewpoint of education. It is to build a learning society and create equal opportunities for all to education and lifelong learning, especially for ethnic minorities, the poor and children living in families with policy beneficiaries (Prime Minister of the Government 2012). And one of education development policies for 2011-2016 period was to make and implement policies to ensure equal opportunities to learning, support and prioritize education development and human resource training for ethnic minorities, disadvantaged areas, social policy beneficiaries and the poor (Prime Minister of the Government 2012).

So far, Vietnam has promulgated many policies and programs regarding to education and created opportunities to access to education for children living in poor households in ethnic minority areas and it is possible to mention about three main groups of policies namely 1/ A group of policies related to scholarships and tuition fee exemptions and meal and accommodation allowances, etc.; 2/ A group of policies related to infrastructure construction and teacher development; 3/ A group of policies related to universal education. It is possible to say that the three groups of policies have created opportunities for the poor to gain access to education and improve their knowledge and qualifications.

\subsubsection{Distance from Home to School}

In the past time, Vietnam has promulgated policies on investments in infrastructure development, including transportation system and educational institutions in poor areas and extremely disadvantaged areas, thus providing favorable conditions for children in such areas to gain access to education. Distance and time from children's home to school in poor areas have been shortened and easily accessible. However, when comparing the communes under the Program 135 and those not under the Program, the average distance from hamlets/villages without educational institutions to the nearest educational institutions is much more different. Children living in communes under the Program 135 have to go farther than those not under the Program 135, especially at higher stages of education. For primary schools, the average distance from hamlets/villages without educational institutions to the nearest ones in the communes under the Program 135 in 2016 is $3.6 \mathrm{~km}$ and in the communes not under the Program 135 is $2.3 \mathrm{~km}$ (more than $1.3 \mathrm{~km}$ ). The distance is very meaningful for children at the primary stage of education because of the shorter distance for them the more opportunities for them to go to school, especially for children living in areas facing many difficulties in traveling.

Table 2. Average distance from hamlets without types of educational institutions to the nearest ones with types of educational institutions in 2016 (unit: km)

\begin{tabular}{ccc}
\hline Types of schools & Communes under Program & $\begin{array}{c}\text { Communes not under } \\
\text { Program 135 }\end{array}$ \\
\hline Primary schools & 135 & 2.3 \\
Lower secondary schools & 3.6 & 2.5 \\
Upper secondary school & 4.2 & 5.1 \\
Combined primary school and lower secondary school & 12.7 & 4.0 \\
Combined lower and upper secondary school & 3.4 & 4.5 \\
\hline
\end{tabular}

Source: General Statistics Office of Vietnam, 2018, p. 738

For lower secondary schools, the average distance from hamlets/villages without educational institutions to the nearest ones in communes under the Program 135 in 2016 is $4.2 \mathrm{~km}$ and ones in communes not under the Program 135 is $2.5 \mathrm{~km}$ (more than $1.7 \mathrm{~km}$ ) and for upper secondary schools, the distance is $12.7 \mathrm{~km}$ and $5.1 \mathrm{~km}$ respectively (more than $7.6 \mathrm{~km}$ ). The data shows that for higher stages of education, the distance from children's home to school in hamlets/villages without educational institutions to the nearest ones in communes under the Program 135 is farther than from communes not under the Program 135. This is an obstacle for children's opportunities to go to school in communes under the Program 135 due to difficulties they face when comparing with the children in communes not under the Program 135. However, in order to provide opportunities to go to 
school for children living in disadvantaged areas, Vietnam has also promulgated many policies on building boarding school systems and meal and accommodation allowances (the Prime Minister of the Government, 2013; the Government, 2016). By 2019, Vietnam has 316 ethnic minority boarding schools in 49 provinces/cities with the total of 109,245 boarding students, increasing by 22 ethnic minority boarding schools and 28,422 boarding students compared to that of school year 2011-2012 (the Ministry of Education and Training, 2019).

\subsection{Acceptability}

In Vietnam, the State has provided allowances and tuition fee exemptions for students living in poor households (National Assembly 2019). Thereby, children living in poor households attending general education at public schools are also exempted from tuition fees. This not only helps such households reduce pressure on tuition fees but also create opportunities for their children to gain access to general education. In households' expenditures, the share of expenditure on education of the poorest group only accounts for 3.9\% (General Statistics Office of Vietnam, 2018). The expenditures on education of poor groups are mainly non-tuition fees (over 80\%), including contribution to school fund, learning tools, textbooks, uniforms, extra courses, etc. The amount of non-tuition fee is not much but it accounts for a big share of the total expenditures on education of poor households and this affects on the opportunities to access to education of the children living in poor households.

Table 3. Expenditure on education and average training fee for a student in 12 months of 2016 (Unit: VND)

\begin{tabular}{ccccccccc}
\hline & & $\begin{array}{c}\text { Tuition } \\
\text { fees }\end{array}$ & $\begin{array}{c}\text { Contribution to } \\
\text { school fund }\end{array}$ & Uniform & Textbooks & $\begin{array}{c}\text { Learning } \\
\text { tools }\end{array}$ & $\begin{array}{c}\text { Extra } \\
\text { courses }\end{array}$ & $\begin{array}{c}\text { Other expenditures } \\
\text { on education }\end{array}$ \\
\hline Group & Amount & 264 & 238 & 130 & 144 & 165 & 179 & 306 \\
1 & $\%$ & 18.5 & 16.7 & 9.1 & 10.1 & 11.6 & 12.6 & 21.5 \\
Group & Amount & 912 & 342 & 215 & 238 & 221 & 466 & 836 \\
2 & $\%$ & 28.2 & 10.6 & 6.7 & 7.4 & 6.8 & 14.4 & 25.9 \\
Group & Amount & 1,228 & 365 & 250 & 265 & 236 & 695 & 1,038 \\
3 & $\%$ & 30.1 & 9.0 & 6.1 & 6.5 & 5.8 & 17.0 & 25.5 \\
Group & Amount & 1,857 & 458 & 290 & 318 & 271 & 1,123 & 1,439 \\
4 & $\%$ & 32.3 & 8.0 & 5.0 & 5.5 & 4.7 & 19.5 & 25.0 \\
Group & Amount & 4,944 & 713 & 354 & 458 & 351 & 1,758 & 2,655 \\
5 & $\%$ & 44.0 & 6.3 & 3.2 & 4.1 & 3.1 & 15.7 & 23.6 \\
\hline
\end{tabular}

Source: General Statistics Office of Vietnam, 2018, p. 141-142.

When comparing expenditures on education and training among living standards groups (see Table 3), it is possible to see significant differences on access to education of the poorest group. Firstly, expenditures on education and training reveal that the amount the poorest group spends on learning services and assistance is lower than that of the richest group. In particular, expenditures on textbooks, learning tools and extra courses are lower than 3.2 times, 2.1 times and 9.8 times respectively. The expenditures are to service and assist students' learning and improve their knowledge. Though extra courses are not a decisive factor for students' knowledge but in the present context of Vietnam, it is difficult to say that the extra courses do not impact on their knowledge enhancement. The research by Huong. D. T. M shows that extra courses deepen inequality in the learning environment as the children living in well-off families have more opportunities to access to teaching programs with better quality outside the school (Huong, 2016, p. 222). Secondly, in terms of sustainable development, inequality in access to education will lead to inequalities in the future life of the children living in poor households. The inequalities can be physical (health, height, weight, etc.), opportunities to get jobs, and so on.

The ability to invest in education depends on households' living standards. For the poorest group, education is not a high priority in its household expenditure structure. Expenditures on education of the poorest group only account for a small proportion of the total household expenditures and nearly two times lower than that of the richest group (3.9\% and 6.1\% respectively) (General Statistics Office of Vietnam, 2018). Besides the small proportion of the expenditure structure, the expenditures on education of the poorest group is over 7.4 times lower than that of the richest group (see Table 5). Living standards and expenditures on education are directly proportional to each other and it means that the higher living standards the greater per capita expenditure on education. 
Table 5. Expenditure on education and average training fee for a student in 12 months of 2016 (unit: 1,000 VND)

\begin{tabular}{ccccccc}
\hline On average & Group 1 & Group 2 & Group 3 & Group 4 & Group 5 & Difference between group 1 and group 5 \\
\hline 5,459 & 1,572 & 3,341 & 4,348 & 5,941 & 11,635 & 7.4 \\
\hline
\end{tabular}

Source: General Statistics Office of Vietnam, 2018, p. 147.

In fact, higher stages of education mean big expenditures on education. For example, at primary education, per capita cost in a year in the poorest group is $821,000 \mathrm{VND}$ but at lower secondary education, it is 1,270,000 VND (about 1.5 times higher than that of primary education) and at upper secondary education, it is 2,623,000 VND (about 2.1 times than that of lower secondary education) (General Statistics Office of Vietnam, 2018). Thus, education costs are a big challenge for poor households to access to education, especially at higher stages of education even if their children are exempted from tuition fees. For children from poorer backgrounds in particular the pressure on them to withdraw from school increases as they get older, particularly as the opportunity cost of their time increases (Hunt, 2008, p. 8). Increasing education costs subject to stages will become an obstacle for narrowing inequalities in access to higher education between the poorest group and the richest group.

Family living standards play an important and decisive role in children's schooling. The researches by Tuan. N. D (2011) and Hoa. T. T. A (2013) and Huong. D. T. M (2016) in Vietnam show that family living standards affect on children's attendance and dropout status. Children living in poor households and ethnic minority children are more likely to drop out of schools sooner than children living in well-off families and Kinh ethnicity families. Children living in poor families and ethnic minority children often have to drop out of school early because their families cannot afford the children's education costs and the children have to stay at home to support their families to earn extra income to pay for their daily costs (see Table 4).

\subsection{Adaptability}

Learning opportunities of children in general and those living in poor households in ethnic minority areas in particular depend not only on education policies, infrastructures (schools, classrooms, educational human resources), localities, economic conditions of families but also on guardians (parents) and children themselves students. To consider adaptability, in this part, we study the causes of dropout among students at all levels. Among the causes, poor people are not able to adapt learning conditions and they have to drop out of school and because of dropout, they loss their learning opportunities. Dropout is usually not from a single cause but it is a process with more than one reason (Hunt, 2008). In Vietnam, according to the Vietnam Household Living Standards Survey 2016, there are eight main reasons for dropping out of or not attending school. Here, we rank these causes in two groups of subjects for consideration.

Table 4. Causes of students dropping out of or not attending schools (unit: \%)

\begin{tabular}{|c|c|c|c|c|c|c|}
\hline \multirow[b]{2}{*}{ Causes } & \multicolumn{3}{|c|}{ Communes under the Program 135} & \multicolumn{3}{|c|}{ Communes not under the Program 135} \\
\hline & Primary & $\begin{array}{c}\text { Lower } \\
\text { secondary }\end{array}$ & $\begin{array}{c}\text { Upper } \\
\text { secondary }\end{array}$ & Primary & $\begin{array}{c}\text { Lower } \\
\text { secondary }\end{array}$ & $\begin{array}{c}\text { Upper } \\
\text { secondary }\end{array}$ \\
\hline Schools too far & 14.4 & 13.8 & 36.3 & 3.9 & 4.5 & 13.6 \\
\hline $\begin{array}{c}\text { Difficult economic } \\
\text { conditions/too high cost }\end{array}$ & 60.5 & 58.2 & 66.4 & 62.7 & 53.1 & 54.7 \\
\hline Illness/diseases & 10.2 & 7.8 & 5.4 & 26.8 & 18.6 & 11.6 \\
\hline $\begin{array}{l}\text { Children are incapable to } \\
\text { learn/dislike going to school }\end{array}$ & 64.7 & 66.0 & 57.4 & 62.7 & 78.2 & 76.4 \\
\hline Over-crowded schools & - & - & - & 1.5 & 0.8 & 1.5 \\
\hline $\begin{array}{l}\text { Parents uninterested in children's } \\
\text { schooling }\end{array}$ & 68.9 & 63.1 & 44.0 & 62.4 & 61.0 & 52.4 \\
\hline Children have to work & 17.4 & 31.0 & 38.6 & 12.1 & 15.1 & 25.6 \\
\hline Language barriers & 11.4 & 5.2 & 2.7 & 3.0 & 1.1 & 0.5 \\
\hline Others & 3.6 & 4.9 & 3.1 & 5.7 & 4.9 & 4.5 \\
\hline
\end{tabular}

Source: General Statistics Office of Vietnam, 2018, p. 747-760. 


\section{Adaptable to the conditions of education providers}

Infrastructure factors such as in shortage of education personnel, over-crowded schools or insufficient seats for children are not the cause that make students living in poor households drop out of school. The policies of Vietnam on investing in building education infrastructure, especially in poor areas, extremely difficult areas and ethnic minority areas show its preeminence. However, from education providers' viewpoint, schools too far and teaching language also impact on the dropout of students living in poor households even though they are not main causes.

The above situation also reflects the reality of transportation and education in ethnic minority areas of Vietnam. Although transportation in these areas has been substantially improved, there are some localities where traveling from home to school is difficult. Besides, as mentioned above, the higher stages of education are the farther distance from home to school is. These reasons partly explain why children living in poor households often drop out of school at higher stages of education. Regarding teaching language, Vietnamese is considered the official language used in Vietnamese educational institutions and ethnic minority children before attending primary schools must be taught and learn Vietnamese (The National Assembly, 2019). Moreover, Vietnam also pays attention to teach the language and writing of ethnic minorities. At present, in Vietnam, there are six languages of ethnic minorities namely Mong, Cham, Kho Me, Gia Rai, Ba Na, E De to be taught in 22 provinces/cities, particularly in 715 schools and 4,812 classes and 113.231 students are learned these languages (the Ministry of Education and Training, 2019). However, for some ethnic minority children, especially those who do not attend public nursery schools, they still face difficulties in learning Vietnamese when they attend primary schools.

\section{Adaptability from the subject himself to education access}

Some researches show that parents' disinterest in their children's education depends on their education (Diaz, 2003; Bhushan, 2001; Long, 2013) and that a mother with a higher stage of education means her child has higher average number of schooling years than a child of a mother with a lower stage of education (Unicef, 2010). This problem is even more evident in poor households because their members are usually low-educated. Moreover, their livelihood makes them spend less time and attention to their children's learning. The data in Table 4 shows that one of main reasons for children living in poor households to drop out of school comes from the lack of parental intention to the children's education, especially at lower stages of education. This also make children's opportunities to access to education decrease.

In addition, the ability of children living in poor households to study and their desire to go to school also affect on opportunities to access to education. Because a child is able to learn and want to go to school, this is a motivation for his parents and himself to seek opportunities to go to school. Whereas, a child is not able to study or does not want to go to school, he will fall in depression and drop out of school. For example, the dropout percentage of students at primary education in communes under the Program 135 due to this reason is $64.7 \%$, at lower secondary education $66.0 \%$ and at upper secondary education $57.4 \%$ (General Statistics Office of Vietnam, 2018). Difference between the language taught in classes and native language (used at home) also impacts on the education ability and the number of years of schooling (Unicef, 2010). Although Vietnam is a multi-ethnic country and there are many ethnic minority groups together with the difference among the language taught in classrooms and native languages but in poor communes, children's dropout rate due to language obstacles is not much (Table 4). However, this is an issue not only for the State to pay attention to but also for ethnic minority families to focus on so that children are well prepared to go to school and master the knowledge learned at classes.

\section{Conclusion}

In Vietnam, together with tuition fee exemption policies, investment policies for building infrastructures for general education such as schools, classrooms and teaching and learning materials in poor localities in ethnic minority areas in the past time also help children living there have more opportunities to access to education. However, in some localities, especially in remote and extremely difficult areas, children living in poor families are still limited to access to general education. The limitation is due to far distance from home to school, difficult roads and non-tuition fee burdens. In addition, parental disinterest, limited learning ability, dislike to going to school, working to support their families and language obstacles partly affect on opportunities to access to education for children living in poor households in ethnic minority areas in Vietnam. Thus, for children living in poor ethnic minority households in remote, extremely difficult areas to go to school, besides continuous investments in building schools, classrooms, tuition fee exemptions, allowances, it is necessary to pay attention to teacher training. Teachers in these areas require to learn the languages of ethnic minorities. This helps teachers provide better knowledge to their students (especially at primary schools as ethnic minority children are not able 
to well listen and speak Vietnamese at the classrooms) as well as understand students' desires and the cultures of ethnic minorities in these areas. Learning the languages of ethnic minorities is important to bring about a friendly learning environment and connection between teachers and students.

From a human development perspective, expanding opportunities to access to education is to improve human capacity. Consequently, the fact that the poor are limited to access to education will lead to their capacity limits, including physical and mental, especially when children are buds of the society. Limited access to education means limited opportunities to earn stable and high income jobs in the future. In addition, the poor's limited knowledge of nutrition and healthcare is limited affects directly on their health. This can easily lead to the vicious circle of poverty and inhibit human development. Thus, for the poor to access to education, Vietnam needs to implement the student-centered education target, expand opportunities for all, including the poor in ethnic minority areas, to access to general education.

\section{Acknowledgement}

This article is the product of the Project CTDT.44.18/16-20 namely "Theoretical and practical issues on human development in ethnic minority areas meet the requirements of industrialization and modernization". Agency in charge: Institute of Human Studies, Vietnam Academy of Social Science.

\section{References}

Central Steering Committee for the Population and Housing Census. (2019). The results of population and housing census at 0 hour on April 1, 2019. Statistical Publishing House.

General Statistics Office of Vietnam. (2018). Results of the Vietnam Household Living Standards Survey 2016, Statistical Publishing House, Hanoi.

Hoa, T. T. A. (2013). Assessing the capability to approach to educational services of the poor in the northern mountainous provinces in the context of education socialization in Vietnam. Ministerial research project, the Vietnam Institute of Educational Sciences.

Huong, D. T. M. (Chief author). (2016). Sustainable development of Vietnamese people to meet the requirements of industrialization and modernization. Social Sciences Publishing House, Hanoi.

Hunt, F. (2008). Dropping out from school: A cross-country review of literature. Retrieved from https://www.researchgate.net/publication/234629293_Dropping_Out_from_School_A_Cross_Country_Rev iew_of_Literature

Tomaševski, K. (2001). Human rights obligations: making education available, accessible, acceptable and adaptable. Right to education primers No. 3. Retrieved from https://www.right-to-education.org/sites/rightto-education.org/files/resource-attachments/Tomasevski_Primer\%203.pdf

Feinstein, L., Sabates, R., Anderson, T. M., Sorhaindo, A., \& Hammond, C. (2006). What are the effects of education on health. In R. Desjardins, \& T. Schuller, (Eds.), Measuring the Effects of Education on Health and Civic/social Engagemen (pp. 171-354). Retrieved from https://escholarship.org/uc/item/6h84705f

Long, T. Q. (2013). Factors affecting the school-leaving age of Vietnamese youth. Journal of Family and Gender Studies, 2, 29-42.

Coley, R. J., \& Baker, B. (2013). Poverty and Education: Finding the Way Forward. The ETS Center for Research on Human Capital and Education. Retrieved from https://www.ets.org/s/research/pdf/poverty_ and_education_report.pdf

School of Law - Vietnam National University, Hanoi. Theory and law curriculum on human rights. Vietnam National University Publishing House.

School of Law - Vietnam National University, Hanoi, Center for human rights and citizenship research CRIGHTS. (2011). Introducing international documents on human rights. Labor - Social Affairs Publishing House, Hanoi.

The Communist Party of Vietnam. (2016). The Political Report of the $11^{\text {th }}$ Party Central Committee at the $12^{\text {th }}$ National Congress of the Communist Party of Vietnam. Retrieved from http://tulieuvankien.dangcongsan. vn/ban-chap-hanh-trung-uong-dang/dai-hoi-dang/lan-thu-xii/bao-cao-chinh-tri-cua-ban-chap-hanh-trung-uo ng-dang-khoa-xi-tai-dai-hoi-dai-bieu-toan-quoc-lan-thu-xii-cua-dang-1600.

The Government. (2011). Decree No. 05/2011/ND-CP on ethnic minorities. Vietnam: Hanoi.

The Government. (2016). Decree No. 116/2016/ND-CP on regulations on policies to support students and 
schools in special districts and rural difficulties. Vietnam: Hanoi.

The Government. (2018). Summary report on evaluating three years of implementing socio-economic development assistance policies for ethinic minority, mountainous areas (in the 2016 - 2018 period). Vietnam: Hanoi.

The Government. (2019). The Master Plan on socio-economic development in ethnic minority and mountainous areas and areas facing expeptionally difficult conditions in the 2021-2030 period. Vietnam: Hanoi.

The Ministry of Education and Training. (2019). Implementation of social policies to promote educational development in ethnic minority and mountainous areas. Retrieved from https://moet.gov.vn/tintuc/Pages/ tin-tong-hop.aspx?ItemID=6295

The Ministry of Labor - Invalids and Social Affairs. (2019). Decision No. 1052/QD-TBLDXH dated on July 29, 2019 on publishing the 2018 poor and to-be-poor household review.

The Ministry of Labor - Invalids and Social Affairs. (2015). Report to the Government on poverty standards 2006-2016. Vietnam: Hanoi.

The National Assembly of the Socialist Republic of Vietnam. (2019). Law on Education. Vietnam: Hanoi.

The National Assembly of the Socialist Republic of Vietnam. (2013). The Constitution of the Socialist Republic of Vietnam. Vietnam: Hanoi.

The Prime Minister of the Government. (2012). Decision No. 711/QD-TTg dated on June 13, 2012 on approving "2011-2020 education development strategy". Vietnam: Hanoi.

The Prime Minister of the Government. (2013). Decision No. 12/2013/QD-TTg dated on January 24, 2013 on regulations on policies to support high-school students in regulations of special socio-economic conditions. Vietnam: Hanoi.

The Prime Minister of the Government. (2016). Decision No. 50/2016/QD-TTg dated on November 3, 2016 on criteria for identifying extremely difficult hamlets and communes in ethnic minority and mountainous areas for 2016-2020 period. Vietnam: Hanoi.

Tuan, N. D. (2011). Expanding choice opportunities and improving capacity building for the poor in Vietnam: raised issues. Journal of Social Sciences Information, 7(343), 3-8.

McCowan, T. (2015). Three dimensions of equity of access to higher education. Compare: A Journal of Comparative and International Education, 46(4), 645-665. https://doi.org/10.1080/03057925.2015.1043237

Unesco. (2010). EFA Global Monitoring Report 2010: Education for All. Retrieved from https://unesdoc.unesco.org/ark:/48223/pf0000186606

United Nations Human rights. Retrieved from https://www.ohchr.org/EN/Issues/Education/Training/ Compilation/Pages/d)GeneralCommentNo13Therighttoeducation(article13)(1999).aspx

Vietnam Academy of Social Sciences and UNDP. (2015). 2015 Vietnam human development report on inclusive growth. Social Sciences Publishing House.

Watkins, K. (2012). The Power of circumstances A new approach to measuring educational inequality. Center for Universal Education. Retrieved from https://www.brookings.edu/wp-content/uploads/2016/06/01_ measuring_educational_inequality_watkins.pdf

\section{Notes}

Note 1. Communes in ethnic minority and mountainous areas are defined following three regions: Communes in region III have extremely difficult socio-economic conditions; those in region II have difficult socio-economic conditions but they are under the stable condition; communes in region I are the remaining (The Prime Minister of the Government, 2016).

Note 2. The Program 135 is the socio-economic development program for extremely difficult communes in ethnic minority and mountainous areas of the Government of Vietnam.

Note 3. Communes under the Program 135 are poor ones; communes not under the Program 135 are not poor ones.

Note 4. Calculations of the author are base on the data from the Statistical Yearbook of Vietnam 2018 issued by General Statistics Office of Vietnam. 


\section{Copyrights}

Copyright for this article is retained by the author(s), with first publication rights granted to the journal.

This is an open-access article distributed under the terms and conditions of the Creative Commons Attribution license (http://creativecommons.org/licenses/by/4.0/). 